\title{
Heat Generation on Implant Surface During Abutment Preparation at Different Elapsed Time Intervals
}

\author{
Al-Keraidis, Abdullah ; Aleisa, Khalil ; Al-Dwairi, Ziad Nawaf ; Al-Tahawi, Hamdi ; Hsu, Ming-Lun ; Lynch,
} Edward ; Özcan, Mutlu

\begin{abstract}
PURPOSE The purpose of this study was to evaluate heat generation at the implant surface caused by abutment preparation using a diamond bur in a high-speed dental turbine in vitro at 2 different water-coolant temperatures. MATERIALS AND METHODS Thirty-two titanium-alloy abutments were connected to a titaniumalloy implant embedded in an acrylic resin placed within a water bath at a controlled temperature of $37^{\circ} \mathrm{C}$. The specimens were equally distributed into 2 groups (16 each). Group 1 : the temperature was maintained at $20 \pm 1^{\circ} \mathrm{C}$; and group 2: the temperature was maintained at $32 \pm 1^{\circ} \mathrm{C}$. Each abutment was prepared in the axial plane for 1 minute and in the occlusal plane for 1 minute. The temperature of the heat generated from abutment preparation was recorded and measured at 3 distinct time intervals. RESULTS Water-coolant temperature $\left(20^{\circ} \mathrm{C}\right.$ vs $\left.32^{\circ} \mathrm{C}\right)$ had a statistically significant effect on the implant's temperature change during preparation of the abutment $(\mathrm{P}$ $<0.0001)$. CONCLUSION The use of water-coolant temperature of $20 \pm 1^{\circ} \mathrm{C}$ during preparation of the implant abutment decreased the temperature recorded at the implant surface to $34.46^{\circ} \mathrm{C}$, whereas the coolant temperature of $32 \pm 1^{\circ} \mathrm{C}$ increased the implant surface temperature to $40.94^{\circ} \mathrm{C}$.
\end{abstract}

DOI: https://doi.org/10.1097/ID.0000000000000600

Posted at the Zurich Open Repository and Archive, University of Zurich

ZORA URL: https://doi.org/10.5167/uzh-146146

Journal Article

Published Version

Originally published at:

Al-Keraidis, Abdullah; Aleisa, Khalil; Al-Dwairi, Ziad Nawaf; Al-Tahawi, Hamdi; Hsu, Ming-Lun; Lynch, Edward; Ȯzcan, Mutlu (2017). Heat Generation on Implant Surface During Abutment Preparation at Different Elapsed Time Intervals. Implant Dentistry, 26(5):700-705.

DOI: https://doi.org/10.1097/ID.0000000000000600 


\title{
ID
}

\section{Heat Generation on Implant Surface During Abutment Preparation at Different Elapsed Time Intervals}

\author{
Abdullah Al-Keraidis, BDS, MSc, ${ }^{*}$ Khalil Aleisa, BDS, MSc, $\dagger$ \\ Ziad Nawaf Al-Dwairi, BDS, MFDSRCPS(Glasg), MFDSRCS Ed, PhD, ‡ Hamdi Al-Tahawi, DDS, MSc, PhD,§ \\ Ming-Lun Hsu, Dr.med.dent, DDS, ๆ Edward Lynch, MA, BDentSc, FDS, PhD, || and Mutlu Özcan, Dr.med.dent, PhD\#
}

$\mathrm{E}$ xcessive surgical trauma is an important cause of formation of a soft tissue layer between the installed dental implant and surrounding bone tissue. ${ }^{1}$ The extent of surgically induced bone necrosis at implant installation is mainly because of the frictional heat generated by bone cutting, although additional tissue trauma may be caused by compression or vibration. One of the factors that influence successful osseointegration is the prevention of excessive heat generation during the bone drilling procedure, or osteotomy preparation. ${ }^{2}$ It has been concluded that bone should not be heated beyond $43^{\circ} \mathrm{C}$ to maintain its vitality. ${ }^{3}$ When temperature exceeds $43^{\circ} \mathrm{C}$, alkaline phosphatase begins to breakdown. Ideally, heat generation should not exceed $39^{\circ} \mathrm{C} .{ }^{3}$ Furthermore,

${ }^{*}$ Consultant Prosthodontist, Dental Center, King Saud Medical City, Riyadh, Saudi Arabia.

†Professor, Department of Prosthetic Dental Sciences, College of Dentistry, King Saud University, Riyadh, Saudi Arabia. †Professor, Department of Prosthodontics, Faculty of Dentistry, Jordan University of Science and Technology, Irbid, Jordan. §Professor and Consultant Prosthodontist (deceased), Department of Prosthetic Dental Sciences, College of Dentistry, King Saud University, Riyadh, Saudi Arabia.

IProfessor and Chairman, Department of Dentistry, National Yang-Ming University, Taipei, Taiwan.

\|Course Director, Dentistry, Warwick Medical School, University of Warwick, Warwick, England.

\#Professor, Dental Materials Unit, Clinic for Fixed and Removable Prosthodontics and Dental Materials Science, Center for Denta and Oral Medicine, University of Zurich, Zurich, Switzerland.

Reprint requests and correspondence to: Ziad Nawaf AL-Dwairi, BDS, MFDSRCPS (Glasg), MFDSRCS Ed, PhD, Department of Prosthodontics, Faculty of

Dentistry, Jordan University of Science and Technology, PO Box 3030, Code: 22110 Irbid, Jordan, Phone:

+00962798895757,E-mail: ziadd@just.edu.jo

ISSN 1056-6163/17/02604-001

Implant Dentistry

Volume 26 - Number 4

Copyright $@ 2017$ Wolters Kluwer Health, Inc. All rights

reserved.

DOI: 10.1097/ID.0000000000000600
Purpose: The purpose of this study was to evaluate heat generation at the implant surface caused by abutment preparation using a diamond bur in a high-speed dental turbine in vitro at 2 different watercoolant temperatures.

Materials and Methods: Thirtytwo titanium-alloy abutments were connected to a titanium-alloy implant embedded in an acrylic resin placed within a water bath at a controlled temperature of $37^{\circ} \mathrm{C}$. The specimens were equally distributed into 2 groups (16 each). Group 1: the temperature was maintained at $20 \pm 1^{\circ} \mathrm{C}$; and group 2: the temperature was maintained at $32 \pm 1{ }^{\circ} \mathrm{C}$. Each abutment was prepared in the axial plane for 1 minute and in the occlusal plane for 1 minute. The tem-

Eriksson and Albrektsson ${ }^{4}$ found that heating the bone to $47^{\circ} \mathrm{C}$ or $50^{\circ} \mathrm{C}$ for 5 minutes significantly reduced bone formation around the implants.

Osseointegration is only possible when the vitality of the bone surrounding the implant is maintained. There is no doubt that thermal damage to the bone may occur in the preparation of an implant bed (osteotomy). The extent of this damage depends on the nature and quality of the cutting tools, the speed of rotation, and whether internal or external irrigation is used during the process. ${ }^{5-8}$ perature of the heat generated from abutment preparation was recorded and measured at 3 distinct time intervals.

Results: Water-coolant temperature $\left(20^{\circ} \mathrm{C}\right.$ vs $\left.32^{\circ} \mathrm{C}\right)$ had a statistically significant effect on the implant's temperature change during preparation of the abutment $(P<0.0001)$.

Conclusion: The use of watercoolant temperature of $20 \pm 1{ }^{\circ} \mathrm{C}$ during preparation of the implant abutment decreased the temperature recorded at the implant surface to $34.46^{\circ} \mathrm{C}$, whereas the coolant temperature of $32 \pm 1^{\circ} \mathrm{C}$ increased the implant surface temperature to $40.94^{\circ} \mathrm{C}$. (Implant Dent 2017;26:1-6) Key Words: titanium-alloy, water bath, thermocouple

High-speed dental handpieces can generate high levels of thermal energy. Temperature changes and thermal stress distribution in teeth resulting from high-speed tooth preparation are functions of rotation speed, type of cutting surface, force, and the nature of coolants. The use of a coolant greatly reduces the effect of heat generated regardless of the rotational speed of the bur. ${ }^{9,10}$ A coolant applied to the bur reduces the heat generated during cutting and increases its cutting rate. ${ }^{11,12}$ The chief purposes of the coolant are to reduce the temperature during cutting 
and to aid in the removal of particulate debris. ${ }^{11,13}$ There are 3 types of coolants available to the dentist; air, water, and water spray (air and water combined). All 3 coolants can be effective in reducing the temperature during cutting. ${ }^{13}$ The air water spray has been found to be the most effective. ${ }^{14}$ In addition, the presence of water spray increases the cutting rate of the bur when cutting enamel compared to the cutting rate when no coolant is used. ${ }^{15}$

During the preparation of the implant abutment, excessive heat generation at the implant bone interface may cause irreversible bone damage and loss of osseointegration. ${ }^{12,16}$ Bragger et $\mathrm{al}^{12}$ assessed in vitro the heat generation within the implant body when preparing titanium implant abutments. They found that preparation of implant abutments did not lead to detrimental effects on peri-implant tissues provided adequate cooling with spray was used. Furthermore, Gross et al ${ }^{16}$ examined in vitro the effects of heat generation at the implant surface caused by abutment reduction with medium extra fine grain diamond and tungsten burs in a high-speed dental turbine. They found that the abutment reduction with a medium diamond using intermittent pressure and normal turbine coolant was unlikely to cause an interface temperature increase sufficient to cause irreversible bone damage or compromise osseointegration.

Aleisa et $\mathrm{al}^{17}$ evaluated the effect of regular and effective water flow on the heat transmission in implants caused during abutment preparation using a diamond bur in a high-speed dental handpiece. They reported that increasing the water flow rate had no effect on the temperature recorded at the implant surface during abutment preparation.

Several implant prosthetic procedures could carry a risk of heat transfer to the bone-implant interface. Examples of such procedures include intraoral preparation of implant abutments or shortening its occlusal height, subgingival preparation of the abutment margins, preparation of abutment grooves for resistance and retention of the final crown, shortening of impression coping screws, or occlusal adjustment of metal or porcelain restorations. Because of issues of heat transfer, sparking, and accuracy of preparation, it has been recommended that implant abutments should be prepared extraorally, and not intraorally. ${ }^{18}$

The purpose of this study was to evaluate in vitro the heat generation at the implant surface generated by abutment preparation using a diamond bur in a high-speed dental turbine handpiece using 2 different air watercoolant temperatures. The null hypothesis was that different coolant temperatures would have no effect on heat generation at implant surfaces during abutment preparations.

\section{Materials and Method}

Four cylindrical solid implants of $4.1 \mathrm{~mm}$ in diameter and $12 \mathrm{~mm}$ in length (Straumann Standard implant; Institute Straumann AG, Basel, Switzerland) were used in this study. The temperature recording system was composed of J-type thermocouple electrodes (Omega Engineering Inc., Stamford, CT) that were attached to a relatively flattened peripheral surface of the implant (Straumann Standard implant) at the cervical facial aspect of its body. The tip of the thermocouple was wired tightly around the implant with another J-type thermocouple wire to ensure an intimate contact with the implant. The other end of the thermocouple was fixed to a connector (J-type; Omega Engineering Inc.) that was used to connect the end of the thermocouple to the temperature monitor (Thermocouple transducer; Omega Engineering Inc.). The implant and thermocouple were embedded in a Teflon casing (Hengshui Jinggong Rubber \& Plastic Products Co., Ltd., Hengshui, China). Silicone sealant material (GE Construction Sealants; General Electric Co., Huntersville, NC) was used to seal the implant and the thermocouple tip within the Teflon casing. In such a manner, the recording system and the implant were totally isolated from any contact with the water or the acrylic block to prevent dissipation of the heat that may be transmitted through the implant body during preparation.

This assembly of implant, thermocouple and Teflon casing was then placed in a special acrylic block
(Hydroplastic, Wareham, MA). The acrylic-resin block was cubic in shape and $80 \mathrm{~mm}$ in each of the 3 dimensions. This acrylic block with the implant and its Teflon mount were immersed in a water bath (GFL Gesellschaft für Labortechnik $\mathrm{mbH}$, Burgwedel, Germany) with a thermostatic temperature-control mechanism maintaining the starting water temperature at $37^{\circ} \mathrm{C}$. A solid abutment of 5.5-mm height (048.541; Institute Straumann AG, Basel, Switzerland) was inserted into the implant and torqued to $35 \mathrm{Ncm}$. The abutment was isolated from the water level by a rubber dam (Hygenic dental dam latex; Coltene/Whaledent AG, Altstatten, Switzerland) tied around the implant at the cervix of the abutment (Fig. 1).

To test the effectiveness and the accuracy of this temperature recording system, calibration was made by a computer program and board (Data Acquisition System; Omega Engineering Inc.). The abutment of each specimen was heated to a specific known temperature and connected to the board of the computer program (Data Acquisition Program) and the temperature was recorded. Also, the recording accuracy of the monitor (Thermocouple transducer) was calibrated by connecting the same specimen of each implant at the same time to this monitor. The monitor recorded the same temperature that was recorded by the computer

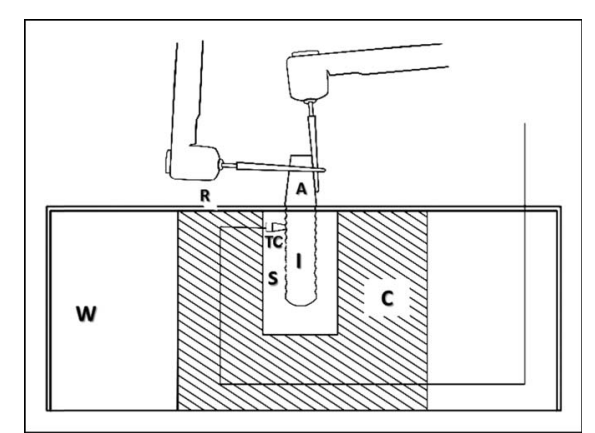

Fig. 1. Schematic representation of experimental setup for temperature measurements after abutment preparation. A: implant abutment; C: acrylic block; I: implant embedded in the Teflon casing; TC: thermocouple attached to the cervical part of the implant; S: Teflon casing sealed with silicon material; $\mathrm{R}$ : rubber dam isolating the water; $\mathrm{W}$ : water bath. 
Table 1. Summary of 2-Way ANOVA of Main Factors Water Coolants and Different Time Intervals) and Their Interaction for implant's Temperature Change

\begin{tabular}{lrrrrc} 
Source & Sum of Square & $d f$ & MS & $F$ & $P$ \\
\hline Coolants & 1315.276 & 1 & 1315.276 & 879.836 & $<0.0001$ \\
Time & 1.100 & 2 & 0.550 & 0.368 & 0.693 \\
Coolants $\times$ Time & 10.901 & 2 & 5.450 & 3.646 & 0.030 \\
Error & 134.542 & 90 & 1.495 & & \\
Total & $137,766.958$ & 96 & & & \\
\hline
\end{tabular}

Water-coolant temperatures $\left(20^{\circ} \mathrm{C}\right.$ vs $\left.32^{\circ} \mathrm{C}\right)$ had statistically significant effects on the implant's temperature change during preparation of the abutment $(P<0.0001)$. In addition, there was no significant differences between the 3 time intervals $(P=0.693)$. $d f$ indicates degrees of freedom; MS, mean square.

program and the same known temperature of the abutment. Four implants were prepared with the recording systems and acrylic blocks.

\section{Preparation of the Abutments}

A high-speed turbine handpiece (W\&H Dentalwerk Bürmoos GmbH, Bürmoos, Austria) with a rotation speed of 390,000 rpm was used at maximum free running-speed with air pressure of 20 psi and water flow rate of 24 $\mathrm{mL} / \mathrm{min}$ and every attempt was made to apply a constant pressure. The abutments were prepared using a coarse, tapered diamond instrument (No. 6836.314.014; Komet $\mathrm{GmbH} \& \mathrm{Co}$. KG, Lemgo, Germany). A new diamond instrument was used for each specimen, and one operator performed all preparations freehand, so that the preparation technique could be regarded as reasonably consistent. Each

\section{Table 2. Implant Temperature}

Changes as Influenced by the Water-

Coolant Temperature When Recorded

at Different Time Intervals After the End of Cutting $(n=16)$

\begin{tabular}{lccc}
\multicolumn{3}{c}{ Water-Coolant } \\
Temperature \\
Time $(\mathrm{s})$ & $\left({ }^{\circ} \mathrm{C}\right)$ & Mean & SD \\
\hline 0 & $20 \pm 1$ & $34.46^{\mathrm{a}}$ & 1.52 \\
0 & $32 \pm 1$ & $40.94^{\mathrm{b}}$ & 1.29 \\
30 & $20 \pm 1$ & $33.70^{\mathrm{a}}$ & 1.26 \\
30 & $32 \pm 1$ & $41.38^{\mathrm{b}}$ & 1.14 \\
60 & $20 \pm 1$ & $33.77^{\mathrm{a}}$ & 0.92 \\
60 & $32 \pm 1$ & $41.83^{\mathrm{b}}$ & 1.12 \\
\hline
\end{tabular}

Mean values designated with the same superscript are not significantly different $(P>0.05)$. The mean temperature recorded immediately when the water-coolant temperature was corded immediately when the water-coolant temperature was
$20 \pm 1{ }^{\circ} \mathrm{C}$ was $33.54^{\circ} \mathrm{C}$, wheras the mean temperature re$20 \pm 1^{\circ} \mathrm{C}$ was $33.54^{\circ} \mathrm{C}$, wheras the mean temperature re-
corded when the water-coolant temperature was $32 \pm 1^{\circ} \mathrm{C}$ was $40.94^{\circ} \mathrm{C}$. This indicated a difference of about a $6.5^{\circ} \mathrm{C}$ higher implant temperature change recorded when the water-coolant temperature was $32 \pm 1^{\circ} \mathrm{C}$ which was statistically significant $(P<0.0001)$ abutment was prepared axially for 1 minute and occlusally for 1 minute. Occlusal reduction or cutting was made with a continuous force for 60 seconds and was intended to cut through the abutment and reduce its height (from the most superior aspect) by $1 \mathrm{~mm}$. Axial reduction or cutting was carried out with a continuous force for $60 \mathrm{sec}$ onds and was intended to simulate abutment contouring. Abutments were replaced after each successive occlusal and axial reduction (cuts). A highvelocity suction tip was held $2 \mathrm{~cm}$ from the abutment to remove the watercoolant spray that collected on the rubber dam. In addition, a 15 minutes interval was required after abutment preparation to allow the implant temperature to return to the starting temperature of $37^{\circ} \mathrm{C}$. The room temperature was $37 \pm 1^{\circ} \mathrm{C}$.

Thirty-two abutments were used in this study. The specimens were equally distributed into 2 groups $(n=16$ each). Group 1: The air water-coolant temperature was $20 \pm 1^{\circ} \mathrm{C}$; and group 2: the air water-coolant temperature was $32 \pm 1^{\circ}$ C. The temperature of heat generation from abutment preparation was measured at 3 distinct time intervals. These elapsed time intervals were: (1) the temperature was recorded immediately after the end of abutment preparation (zero second); (2) the temperature was recorded 30 seconds after the end of preparation (30 seconds); (3) the temperature was recorded 60 seconds after the end of preparation (60 seconds).

\section{Statistical Analysis}

Data were analyzed using a statistical software package (SPSS Software V.16; Chicago, IL). KolmogorovSmirnov and Shapiro-Wilk tests were used to test normal distribution of the data. As the data were normally distributed, 2-way ANOVA and $t$ test were applied to analyze possible differences between the groups for the parameters studied. $P<0.05$ was considered to be statistically significant in all tests.

\section{Results}

Two-way ANOVA revealed that the water-coolant temperatures $\left(20^{\circ} \mathrm{C}\right.$ vs $32^{\circ} \mathrm{C}$ ) had statistically significant effects on the implant's temperature change during preparation of the abutment $(P<0.0001)$ (Table 1$)$. In addition, there were no significant differences between the 3 time intervals $(P=0.693)$. The overall means and SDs of the implant's temperature at 3 different time intervals after the end of each cutting when the water-coolant temperature was $20 \pm 1^{\circ} \mathrm{C}$ and $32 \pm$ $1^{\circ} \mathrm{C}$ are shown in Table 2 . The mean temperature recorded immediately when the water-coolant temperature was $20 \pm 1^{\circ} \mathrm{C}$ was $33.54^{\circ} \mathrm{C}$, whereas the mean temperature recorded when the water-coolant temperature was $32 \pm 1^{\circ} \mathrm{C}$ was $40.94^{\circ} \mathrm{C}$. This indicated a difference of about a $6.5^{\circ} \mathrm{C}$ higher implant temperature change recorded when the water-coolant temperature was $32 \pm 1^{\circ} \mathrm{C}$, which was statistically significant $(P<0.0001)$. The effect of the water-coolant temperature in changing the temperature of the implant continued even after the end of preparation. This effect was determined by recording the temperature changes 30 and 60 seconds after the end of the preparation. A difference in implants temperature of $7.6^{\circ} \mathrm{C}$ was recorded 30 seconds after abutment preparation completion for the warmer water $(P<0.0001)$. A difference in implants temperature of $8.1^{\circ} \mathrm{C}$ was recorded 60 seconds after abutment preparation completion for the $32 \pm 1^{\circ} \mathrm{C}(P<0.0001)$.

\section{Discussion}

Measurement of temperature changes associated with the preparation of an abutment attached to an implant is complicated for 2 reasons. First, the thermal conductivity of titanium is lower than other materials used for 
dental restorations; therefore, significant temperature differences exist between the thermocouple locations and the cutting location. Second, as the cutting proceeds, the geometry changes makes the temperature measurement difficult to interpret. ${ }^{9}$

The temperature of the water coolant itself is an effective tool in reducing the temperature during cutting. The heat generated can be dissipated by conduction through the cutting tool, by conduction through the material being cut or by the chip itself as it is removed, and by the coolant. Consequently, when the water-coolant temperature is low, more heat is dissipated through this cool water, which will absorb most of the heat generated during cutting. Such dissipation of heat by the cool water spray also reduces the amount of heat absorbed by the material being cut. Another important factor in generating heat is the period of time during which the bur is applied to the subject (tooth or abutment). Intermittent cutting at intervals of a few seconds should be the rule. It has been shown that by removing the bur from the tooth intermittently for even a few seconds during crown or abutment preparation can reduce the heat generation considerably..$^{9,14}$

The results of the study have clearly shown that cutting the implant abutment using water-coolant temperature of $20 \pm 1^{\circ} \mathrm{C}$ will not increase the implant surface temperature from the starting temperature of $37^{\circ} \mathrm{C}$ but rather it will cause a decrease in the implant fixture surface temperature. Cutting the implant abutment using a water-coolant temperature of $32 \pm$ $1^{\circ} \mathrm{C}$ did cause an increase in the implant fixture surface temperature which increases to $41.8^{\circ} \mathrm{C}$ from the starting temperature of $37^{\circ} \mathrm{C}$. Therefore, the results of this study led to the rejection of the null hypothesis that the different water-coolant temperatures would have no effect on heat generation at implant surfaces during abutment preparation.

It was also found that the time elapsed after the end of cutting caused changes in the implant surface temperature. The temperature decreased when the water-coolant temperature was $20 \pm 1{ }^{\circ} \mathrm{C}$ and increased when the water-coolant temperature was $32 \pm$ $1^{\circ} \mathrm{C}$. This difference can be explained by the fact that the heat generated during cutting had probably dissipated by conduction through the bur, by conduction through the implant abutment and implant body, and by the water coolant. Accordingly, when the water coolant temperature was low enough, most of the heat generated during cutting was dissipated. This dissipation prevented the heat from dissipating through the implant abutment and the implant body, which caused reduction in the temperature recorded on the surface of the implant. After the end of cutting, the coolant's effect continues to act on the implant abutment and the coolant's dissipation effect continues causing more change in the temperature at the surface of the implant. Although heat dissipation continues after cutting, it is expected to be at a much slower rate than during cutting.

Gross et $\mathrm{al}^{16}$ found that cutting implant abutments for not more than 30 seconds with water coolant that had a temperature of $20 \pm 1^{\circ} \mathrm{C}$ caused the implant surface temperature to be around $36^{\circ} \mathrm{C}$ from a starting temperature of $37^{\circ} \mathrm{C}$. The present study showed that cutting an implant abutment for not more than 60 seconds with water coolants that had a temperature of $20 \pm 1{ }^{\circ} \mathrm{C}$ would not increase the implant surface temperature but rather it would cause a reduction in the temperature recorded from a starting temperature of $37^{\circ} \mathrm{C}$. Therefore, the reduction in implant surface temperature reported in this study is significantly higher than reported by Gross et al. ${ }^{16}$

Bone should not be heated beyond $43^{\circ} \mathrm{C}$ to maintain its vitality. Using vital microscopy, Eriksson and Albrektsson $^{4}$ observed bone tissue after exposure to $50^{\circ} \mathrm{C}$ for 5 minutes, $47^{\circ} \mathrm{C}$ for 5 minutes and $47^{\circ} \mathrm{C}$ for 1 minute. In the first 2 situations, bone was replaced by fat cells; whereas the exposure to $47^{\circ} \mathrm{C}$ for just 1 minute did not induce any changes. The authors concluded that $47^{\circ} \mathrm{C}$ was the maximal temperature for occurrence of morphologically evident bone tissue damage. It is known that when temperatures exceed $43^{\circ} \mathrm{C}$, alkaline phosphatase begins to break down; ideally heat generation should not exceed $37^{\circ} \mathrm{C}$. The in vitro set up of the present study obviously could not document reactions of cells or tissues.

Based on the above, it was concluded that cutting the implant abutment for not more than 1 minute continuously using water-coolant temperature of $20 \pm 1^{\circ} \mathrm{C}$ and water-coolant flow not less than $24 \mathrm{~mL} / \mathrm{min}$ was an appropriate and safe method of implant abutment preparation. Such a procedure will not cause a harmful increase in the heat generation at the implant-tissue interface. However, should titanium implant abutments be prepared without adequate cooling, the critical temperature can be reached within only a few seconds. These findings may indicate that intraoral preparation of abutments with warm water-coolant temperature can cause temperature fluctuations of the implant body. The rise in surface temperature could then be related to potential implant complications if the heat transfer can be found to have an effect at the bone-to-implant interface. Therefore, to avoid any potential of injuring the surrounding bone, accuracy of the preparation, and other conventional prosthetic issues, it may be recommended that abutments should be prepared extraorally rather than intraorally. ${ }^{18}$ Further research is needed to investigate these issues.

In the oral environment, extreme acidic conditions do not exist, but the constant aqueous environment coupled with the biofilm effect, fatigue forces, and possible interaction with other metals in the mouth may impair the passive surface oxide film. ${ }^{19}$ In this respect, after abutment preparation as studied in this investigation can breach the protective oxide layer formed on the surfaces of these passive materials and affect the mechanical and chemical integrity of the implant and the health of the surrounding tissue. After preparation, eventually, implant surface properties such as roughness, chemistry, and energy directly influences tissue response by affecting protein adsorption and modulating cell proliferation and differentiation. ${ }^{20}$ Also, such 
interruptions may result in surface microcracks, increased corrosion rates and, thus, increased corrosion currents that may affect surrounding cells and tissues. ${ }^{21,22}$ Implant failure in the form of aseptic loosening, or osteolysis, may result from metal release in the form of wear debris or electrochemical products generated during corrosion events. ${ }^{23,24}$ Metal ions such as $\mathrm{Ti}^{+}, \mathrm{Co}^{2+}$, and $\mathrm{Al}^{3+}$ have been shown to decrease DNA synthesis, mitochondrial dehydrogenase activity, mineralization, and mRNA expression of alkaline phosphatase and osteocalcin in ROS 17/2.8 cells. ${ }^{25}$ Similarly, phagocytosis of Ti particles caused cytotoxicity in a concentration-dependent manner in rat calvarial osteoblasts and MG63 cells. ${ }^{23,24}$ Therefore, dispersion of titanium debris in the mouth from the abutment preparation or implant surface should be avoided.

The study represents a preparation of a removable abutment that is being performed in a simulated situation that would represent the implant placed within the oral cavity. The problem is that, within the oral cavity there will be vital tissues with circulating blood supply that is difficult to simulate in an in vitro setting. The use of warm water coolant seems to be counterintuitive, whereas the use of room temperature water would.

The preparation for 1 minute on the axial surface in 1 minute on the occlusal surface may take longer in a clinical situation as titanium is a time-consuming material to prepare. These aspects should be verified in clinical settings.

\section{Conclusion}

From this study, the following conclusions could be drawn:

1. The temperature of the water coolant during successive clinical occlusal and axial reduction of titanium implant abutments affected the temperature recorded at the titanium implant surface.

2. The water-coolant temperature of $20 \pm 1{ }^{\circ} \mathrm{C}$ during the preparation of the abutment decreased the mean temperature recorded at the implant surface to $34.46^{\circ} \mathrm{C}$ but temperature of $32 \pm 1^{\circ} \mathrm{C}$ increased the mean temperature recorded at the implant surface to $40.94^{\circ} \mathrm{C}$.

3. Thermal stress distribution and consequently, bone necrosis, could be decreased when watercoolant temperature of $20 \pm 1^{\circ} \mathrm{C}$ is practiced during implant abutment preparation.

\section{Disclosure}

The authors claim to have no financial interest, either directly or indirectly, in the products or information listed in the study.

\section{ApProval}

This is an in vitro study.

\section{Contribution/Role by Co- \\ AUTHORS}

A. Al-Keraidis, K. Aleisa, and $\mathrm{H}$. Al-Tahawi: had the idea, prepared the specimens, performed the experiments, monitored the specimens preparations, and wrote the manuscript. Z. N. AlDwairi, M.-L. Hsu, E. Lynch and M. Özcan: contributed to the hypothesis, experimental design, proofread the manuscript, consulted on statistical evaluation, and contributed to writing the manuscript. All authors discussed the results and commented on the manuscript at all stages.

\section{ACKNOWLEDGMENTS}

The authors thank the College of Dentistry Research Center and the Deanship of Scientific Research at King Saud University for the support of this research.

\section{REFERENCES}

1. Brånemark PI, Adell R, Breine U, et al. Intraosseous anchorage of dental prosthesis: I experimental studies. Scand J Plast Reconstr Surg. 1969;3:81-100.

2. Albrektsson $\mathrm{T}$, Brånemark PI, Hansson $H A$, et al. Osseointegrated titanium implants. Requirements for ensuring a long-lasting direct bone anchorage in man. Acta Orthop Scand. 1981;52:155-170.
3. Hobo S, Ichida E, Garcia LT. Introduction. In: Hobo S, Ichida E, Garcia LT, eds. Osseointegration and Occlusal Rehabilitation. London, United Kingdom: Quintessence Publishing Co; 1999:3-19.

4. Eriksson AR, Albrektsson $T$. Temperature threshold levels for heatinduced bone tissue injury: A vitalmicroscopic study in rabbit. J Prosthet Dent. 1983;50:101-107.

5. Schuchard A, Watkins EC. Comparative efficiency of rotary cutting instruments. J Prosthet Dent. 1965;15: 908-923.

6. Haider R, Watzek G, Plenk $H$. Effects of drill cooling and bone structure on IMZ implant fixation. Int J Oral Maxillofac Implants. 1993;8:83-91.

7. Iyer S, Weiss C, Mehta A. Effects of drill speed on heat production and the rate and quality of bone formation in dental implant osteotomies. Part I: Relationship between drill speed and heat production. Int J Prosthodont. 1997;10:411-414.

8. Reingewirtz Y, Szmukler-Moncler S, Senger B. Influence of different parameters on bone heating and drilling time in implantology. Clin Oral Implants Res. 1997;8:189-197.

9. Peyton FA. Effectiveness of water coolants with rotary cutting instruments. J Am Dent Assoc. 1958;56:664-675.

10. Laforgia PD, Milnao V, Morea C, et al. Temperature change in the pulp chamber during complete crown preparation. J Prosthet Dent. 1991;65: 56-61.

11. Watanabe F, Tawada $Y$, Komatsu $S$, et al. Heat distribution in bone during preparation of implant site: Heat analysis by real-time thermography. Int J Oral Maxillofac Implants. 1992;7:212-219.

12. Bragger $U$, Wermuth W, Torok E. Heat generated during preparation of titanium implants of the ITT dental implant system: An in vitro study. Clin Oral Implants Res. 1995;6:254-259.

13. Vukovich ME, Wood DP, Daley TD. Heat generated by grinding during removal of ceramic brackets. Am J Orthod Dentofacial Orthop. 1991;99:505-512.

14. Sarrett DC, Reitz CD. Heat generated when threaded pins are cut: $A$ comparison of techniques. I Prosthet Dent. 1984;52:46-49.

15. Siegel SC, von Fraunhofer JA. Irrigating solution and pressure effects on tooth sectioning with surgical burs. Oral Surg Oral Med Oral Pathol Oral Radiol Endod. 1999;87:552-556.

16. Gross M, Laufer BZ, Ormianar Z. An investigation on heat transfer to the implant-bone interface due to abutment preparation with high-speed cutting instruments. Int J Oral Maxillofac Implants. 1995;10:207-212. 
17. Aleisa K, Alkeraidis A, Al-Dwairi ZN, et al. Implant fixture heat transfer during abutment preparation. J Oral Implantol. 2015;41:264-267.

18. Ganz SD, Desai N, Weiner S. Marginal integrity of direct and indirect castings for implant abutments. Int J Oral Maxillofac Implants. 2006;21:593-599.

19. Gittens RA, Olivares-Navarrete R, Tannenbaum R, et al. Electrical implications of corrosion for osseointegration of titanium implants. J Dent Res. 2011;90:1389-1397.
20. Schwartz Z, Boyan BD. Underlying mechanisms at the bone-biomaterial interface. J Cell Biochem. 1994;56:340-347.

21. Papakyriacou M, Mayer H, Pypen C, et al. Effects of surface treatments on high cycle corrosion fatigue of metallic implant materials. Int J Fatigue. 2000;22: 873-886.

22. Özcan M, Hammerle C. Titanium as a reconstruction material in dentistry: Advantages and pitfalls. Materials. 2012; 5:1528-1545.
23. Dorr LD, Bloebaum R, Emmanual $\mathrm{J}$, et al. Histologic, biochemical, and ion analysis of tissue and fluids retrieved during total hip-arthroplasty. Clin Orthop Relat Res. 1990:82-95.

24. Jacobs JJ, Urban RM, Hallab NJ, et al. Metal-on-metal bearing surfaces. J Am Acad Orthop Surg. 2009;17:69-76.

25. Sun ZL, Wataha JC, Hanks CT. Effects of metal ions on osteo- blast-like cell metabolism and differentiation. J Biomed Mater Res. 1997;34:29-37. 